\title{
Developing Encyclopedia Media on Form and Function of Plant to Train Elementary Students' Critical Thinking Skill
}

\author{
Yeny Erawati ${ }^{1, a^{*}}$, Raharjo $^{1, b}$, and Utiya Azizah ${ }^{1, c}$ \\ ${ }^{1}$ Elementary Education Study Program, Postgraduate, State University of Surabaya, Indonesia \\ a yeny.18089@mhs.unesa.ac.id; b raharjo@unesa.ac.id; c utiyaazizah@unesa.ac.id \\ *Corresponding Author \\ Whatsapp Numbeer: [08121614946]
}

How to Cite : Erawati, Y., Raharjo, R., Azizah, U. (2020). Developing Encyclopedia Media on Form and Function of Plant to Train Elementary Students' Critical Thinking Skill. International Journal for Educational and Vocational Studies, 2(6), 401-406. DOI: https://doi.org/10.29103/ijevs.v2i6.2514

\section{ARTICLE HISTORY}

Received: 11 March 2020

Revised: 24 April 2020

Accepted: 8 May 2020

KEYWORDS

Critical Thinking Skil;

Encyclopaedia Media;

Discovery Learning model;

\section{ABSTRACT}

This study aims to develop effective, feasible, and valid encyclopedia media on form and function of plant to train fourth-graders' critical thinking skills in the elementary school. This study was research and development based on Borg and Gall theory and Research (R\& D) model. Data were collected using observation, questionnaires, and tests and analyzed using media validity and reliability, student activity, implementation of lesson plans, and tests of critical thinking skills. After that, the media was validated by experts. The results of the expert validation showed that the Encyclopedia media was valid for use. Furthermore, the media was tested on fourth-graders of SDN KERTAJAYA V / 211 Surabaya using One Group Pretest-Posttest Design. The limited scale trial results showed (1) the validation of the developed Encyclopedia media were $96 \%$ valid categories, (2) the developed media were tested in term of lesson plan implementation were $94 \%$ with well-implemented category and student activities were suitable to Discovery Learning model, (3) the effectiveness of the Encyclopedia media in terms of students' critical thinking skills tests showed that average N-Gain was 0.75 (high) and positive response of $97 \%$ was given by students. Therefore, it can be concluded that the Encyclopedia media on Form and Function of Plant is feasible to train Critical Thinking Skills of Elementary School Students.

This is an open access article under the CC-BY-SA license.

\section{INTRODUCTION}

Education is one of the sectors in Indonesia that still develops. In the Education 4.0, Educators not only transfer knowledge but also play as facilitators in directing and guiding students to become critical, creative, innovative, and civilized (Trisnawati, 2018). Teaching and learning processes occur that are mutually beneficial between the teacher and students resulting in good cooperation (Pebriana, 2017).

Media is the equipment used to ease someone to do something, including in the teaching and learning process. Currently, the media as a product of communication technology plays an important role in achieving success in the teaching and learning process. The use of media based on the senses involved according to Rudi Bretz in (Munadi, 2013) is classified into three main elements namely sound, visual, motion. The sound element is involving the sense of hearing and visual is involving the sense of sight. Visual media can be developed by using books, modules, encyclopedias, comics, journals, magazines, visual boards (Munadi, 2013). The element of motion can be developed with objects that can be moved. From the above review, researchers conducted the development of visual media by creating Encyclopedia media.

The encyclopedia is one of the learning media that can be used by students with the teachers' assistance (self-instructional media). Encyclopedia media are based on paper in the form of books (Mustaji, 2013). Other studies have shown that digital encyclopedia media can develop cognitive aspects of early childhood. Besides, the Encyclopedia has many interesting images and colors so that children feel interested in reading (Supriatin, 2018). The handbook used by students has not explained the material of shapes and plants in a complex way so that media development is needed to deepen the material. This study was aimed to develop material which helps students to observe inside structure and plant body so that they have the idea of making Encyclopedia media. This opinion was supported by (Prihartanta, 2015) Encyclopedia book 
is a number of writings that contain explanations that provide information and are easily understood about the whole branch of science or specifically in one branch arranged in alphabetical order, category or volume of publication. (Firdha Bella, 2019). According to Mustaji (2013), the material presented in the Encyclopedia is in the form of information that contains visual elements. therefore, students prefer reading books full of pictures and color that is visualized in a realistic form

The observations from several schools showed that not all teachers used the media as planned before the learning process. In general, they use insufficient media when explaining science so that students get little knowledge from the media and material. The lack of teachers' readiness in using the media will affect students' understanding. besides the learning outcomes of natural science materials tends to decrease because students only imagine the parts and functions of plants. From this obstacle, the researchers created Encyclopedia media that would help students deepen plant material and its parts to practice critical thinking skills.

The development of Encyclopedia media was based on Discovery Learning model to motivate students to complete their tasks and find answers themselves. In the use of Encyclopedia media, researchers choose the Discovery Learning model so that students can solve problems independently and have critical thinking skills, because students must analyze and manage information. This learning model is supported by previous research (Hafrah, 2015) based on these data shows that the average score of the discovery learning learning model is higher than the inquiry learning model to improve critical thinking skills

Involving students in learning process can foster their critical thinking. The strategies that involve participation in learning will make it more meaningful and train students in critical thinking (Shahzada, 2017). Critical thinking according to Zubaidah (2010) process and ability to understand the basic material and analyze the knowledge gained or produced.

Based on the problems above, this study aims to develop effective, feasible, and valid encyclopedia media on form and function of plant to train fourth-graders' critical thinking skills in the elementary school.

\section{METHODS}

The study was conducted in January 2020 for fourth-graders of SDN Kertajaya V/211, Surabaya, Indonesia. The trial was conducted by 12 students. The instrument of this study was the observation, pretest-posttest questions and questionnaires approved by the state university of Surabaya, Indonesia.

\subsection{Research \& Development Method (R\&D)}

This study used R\&D research adapted from Bord and Gall theory (1983). There are 10 steps according to Bord and
Gall media (Siti Imma, 2019). The researcher only used seven stages, as described in the procedure below:.

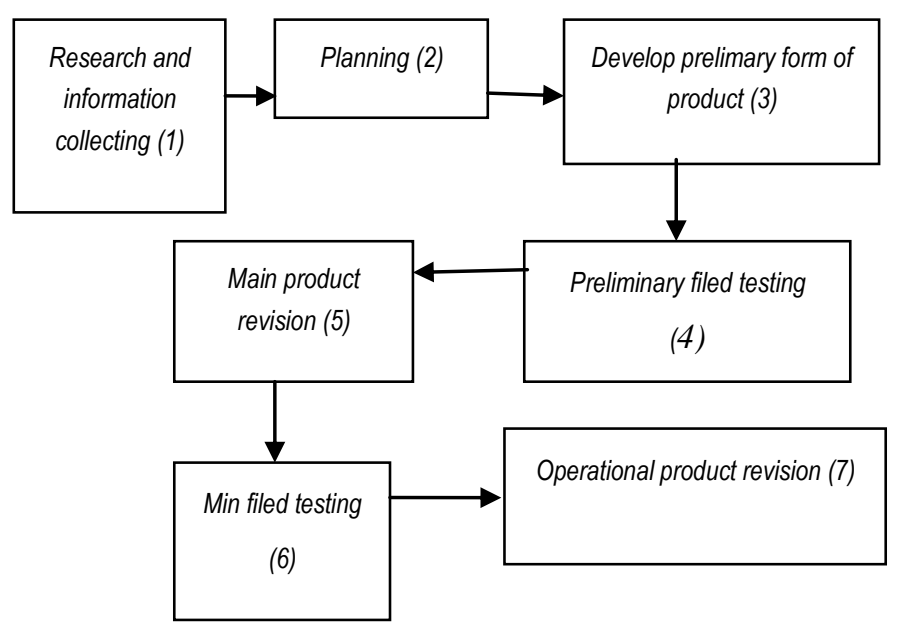

Figure 1. The procedure adapted from Borg and Gall, 1983 in (Setyosari, 2010)

\subsection{One Group Pretes - Protest Design}

One Group Pretes - protest design was used to test one group (Jodian, 2019) described as follows:

Tabel 1. One Group Pretes - Postes Design

\begin{tabular}{ccc}
\hline Pretest & Treatment & Posttest \\
\hline $\mathrm{O}_{1}$ & $\mathrm{X}$ & $\mathrm{O}_{2}$ \\
\hline
\end{tabular}

(Riyanto, 2012)

Description:

O1 : Pretestscore

$\mathrm{X}$ : Treatment

O2 : Post Test Score

\subsection{Validity and Reliability measurement}

The percentage of media validity is measured quantitatively by

$$
\frac{\sum X}{\sum X i} \times 100 \%
$$

(P) = Description:

$\mathrm{P}=$ percentage

$\sum \mathrm{X}=$ the amount of total score

$\sum \mathrm{Xi}=$ the amount of ideal score

The results of the validation are calculated so that the criteria for validity level of madia can be determined as presented in table 1 . 
Table 2. Criteria for Media Validity Level

\begin{tabular}{cc}
\hline percentage & Validity criteria \\
\hline $76-100$ & Valid \\
$56-75$ & Valid enough \\
$40-55$ & Less valid \\
$0-39$ & Invalid \\
\hline
\end{tabular}

Source: (Arikunto, 2006)

The reliability of the encyclopedia media instruments was analyzed using Percentage of Agreement (PA) with the following equation:

Precentage of Agreement $=$

$\left[1-\frac{\mathrm{A}-\mathrm{B}}{\mathrm{A}+\mathrm{B}}\right] \mathrm{X} 100 \%$

(Borich, dalam Ibrahim, 2005)

Description:

$\mathrm{A}=$ the highest frequency of score reporting from the validator

$\mathrm{B}=$ the lowest frequency of score reporting from the validator

Media instruments are said to be reliable if they get a percentage of agreement value of $\geq 75 \%$

\subsection{Statistical calculation of critical thinking skills}

$\frac{\text { Spost-Spre }}{\text { Smaks-Spre }}$, Normalized Gain shows differences in students' critical thinking skills before and after learning with the Discovery Learning model. Normalized Gain scores indicate the level of effectiveness obtained from the pretest and posttest scores. To calculate N-Gain the following equation is used:

$(\mathrm{g})=$

(Hake, R, 1999)

Descriptionn:

(g) = gain score

Spost $\quad=$ post score

Spre $\quad=$ Pretest Score

Smaks = Maximum score

Furthermore, the $\mathrm{N}$-gain scores are converted with the following criteria:

Table 3. Normalized Gain Criteria

\begin{tabular}{cc}
\hline$N$-Gain score & Criteria \\
\hline $\mathrm{N}$-Gain $>0.70$ & High \\
\hline $0,30 \leq \mathrm{N}$-Gain $\leq 0.70$ & Medium \\
\hline $\mathrm{N}$-Gain $<0,30$ & Low \\
\hline
\end{tabular}

(Hake, R, 1999)

\section{RESULTS AND DISCUSSION}

\subsection{Validity and Reliability Calculation Results}

The validation and reliability of Encyclopedia media on Form and Function of plant has been carried out by two validators who are experts in their fields. After validation, the results are used to see the feasibility level of the developed Media before testing.

Table 4. Media Validation and Reliability Results

\begin{tabular}{|c|c|c|c|}
\hline Assessment Aspects & $\begin{array}{l}\text { The Highest } \\
\text { Percentage }\end{array}$ & $\begin{array}{l}\text { The Lowest } \\
\text { percentage }\end{array}$ & $\begin{array}{c}\text { Valid } \\
\text { Criteria } \\
\end{array}$ \\
\hline $\begin{array}{l}\text { Presentation } \\
\text { technique }\end{array}$ & \multirow{5}{*}{$100 \%$} & \multirow{5}{*}{$60 \%$} & \multirow{5}{*}{ Valid } \\
\hline Image properness & & & \\
\hline Quality & & & \\
\hline Language & & & \\
\hline Critical thinking & & & \\
\hline $\begin{array}{l}\text { Percentage of } \\
\text { Agreement (PA) }\end{array}$ & & $5 \%$ Reliable & \\
\hline
\end{tabular}

(Source: Data analysis)

As illustrated from the table above showed that presentation techniqu was $80 \%$; image properness was $100 \%$; the quality was $90 \%$; linguistic aspect was $80 \%$; critical thinking was $96 \%$. While, the obtained average score of the five aspects was $96 \%$ with a valid category, meaning that Encyclopedia media was valid and feasibly used. The reliability of the analysis resultsshowed that the percentage of agreement was 95\%,categorized as reliable criteria.

Media validation and reliability of the Encyclopedia on Form and Function of plant was carried out by two validators who are experts in their fields. After validation, the results were used to see the feasibility level of the media before testing.

Table 4. Media Validation and Reliability Results

\begin{tabular}{|c|c|c|c|}
\hline Assessment Aspects & $\begin{array}{l}\text { The Highest } \\
\text { Percentage }\end{array}$ & $\begin{array}{l}\text { The Lowest } \\
\text { percentage }\end{array}$ & $\begin{array}{c}\text { Valid } \\
\text { Criteria }\end{array}$ \\
\hline $\begin{array}{l}\text { Presentation } \\
\text { technique }\end{array}$ & \multirow[t]{5}{*}{$100 \%$} & \multirow[t]{5}{*}{$60 \%$} & \multirow[t]{5}{*}{ Valid } \\
\hline Image properness & & & \\
\hline Quality & & & \\
\hline Language & & & \\
\hline Critical thinking & & & \\
\hline $\begin{array}{l}\text { Percentage of } \\
\text { Agreement (PA) }\end{array}$ & & $\begin{array}{c}95 \% \\
\text { Reliable }\end{array}$ & \\
\hline
\end{tabular}

From the table above showed that presentation techniquewas 80\%; image properness was $100 \%$; the quality was 90\%; linguistic aspect was $80 \%$; critical thinking was $96 \%$. While, the obtained average score of the five aspects was $96 \%$ with a valid category, meaning that Encyclopedia media was valid and feasibly used. The reliability of the analysis resultsshowed that the percentage of agreement was 95\%,categorized as reliable criteria.

The implementation of learning requires the presence of reports and observations made every time face to face. 
Learning is done in 3 meetings for $4 \times 45$ minutes. UsingDiscovery Learning model, it can be seen in Figure 2 .

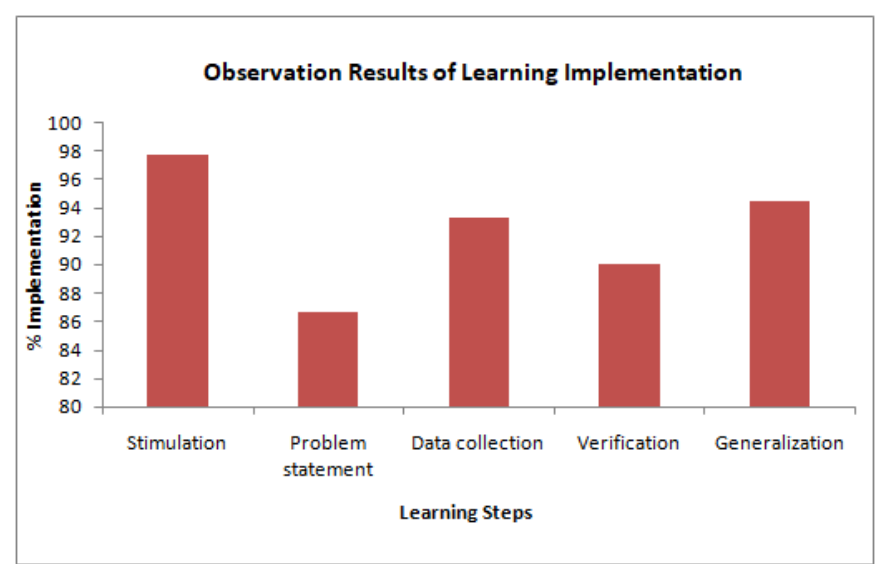

Figure 2. Observation Results of Learning Implementation

As illustrated above, the percentage result of lesson plan validation using Discovery Learning model consisted of five steps. In the stimulation obtained $98 \%$ carried out well. In the learning implementation obtained $86 \%$ where students were asked to find the problem. In the data collection obtained $94 \%$ of learning achievement where students are asked to collect data in the experiment.In the verification of learning implementation obtained $90 \%$, where students proved the results of the experiment with the truth of the material available in the Encyclopedia media. While, at the last stage in drawing conclusions at the end of the learning obtained $90 \%$ of accomplishment.

The results of the students' activities during the activity were observed by two observers at each meeting. Observations were made with three meetings which were suspended along with the implementation of the lesson plan.

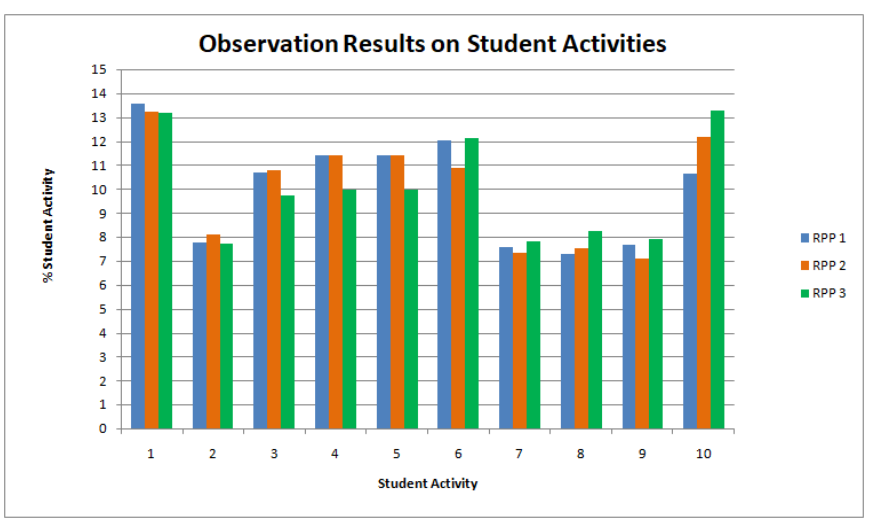

Figure 3. Observation Results on Student Activities

There are ten activities of students starting from listening to the teacher's explanation, asking, answering, reading the media, working student worksheet, discussing, presenting the results of the experiment, expressing opinions, writing relevant composition and making conclusions presented in Figure 3 observed by two observers. the result of students' activities when listening seriously to the teacher's explanation was $13-14 \%$ while the activity of making conclusions increased each meeting from $12-14 \%$. In other activities were between $7-12 \%$, where there are no activities that have the lowest or highest percentage of activities. the activity was categorized as active because students listened to the teacher's direction and discussed seriously not much joking. The linkages of the implementation criteria of learning (Riduwan, 2010) that the use of teaching materials are oriented to the scientific categories that fall into the category of active scoring.

\subsection{The Calculation of Critical Thinking skills}

The effectiveness of Encyclopedia media by using the Discovery Learning model can be seen from the results of students 'critical thinking tests and students' responses. The effectiveness of the media was tested during a limited scale trial conducted in January 2020. The critical thinking indicators that were trained showed simple explanations, building basic skills and making conclusions.

Encyclopedia media was developed to improve students' critical thinking skills and used limited trials to find out the results. The trial will be carried out through several stages, namely students are given pretest to find out the results at the beginning, then learning with the Discovery Learning model using Encyclopedia media and ending with posttest then analyzed with the N-Gain formula. Pretest and posttest results of critical thinking learning outcomes in limited trials are presented in figures 4,5 and 6 .

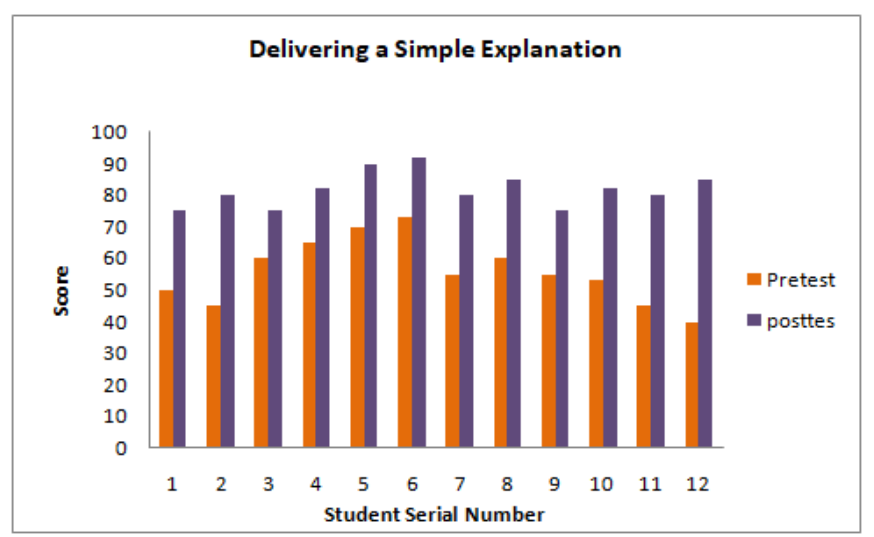

Figure 4. Graph of Calculation Results for improving Critical Thinking with indicators of simple explanation.

Students who obtained the lowest score on the pretest results were in sequence number four and twelve of 40 , where there was an increase in the posttest results of 80 . Students who obtained 75 were 3 students in the pretest, while the results of two students' posttest scores were 90 . From the figure above, the lowest pretest score was 45 and the highest score was 75 . The lowest posttest score was 75 and the highest score was 92 .

The results of critical thinking skills in building basic skills are presented in Figure 5. 


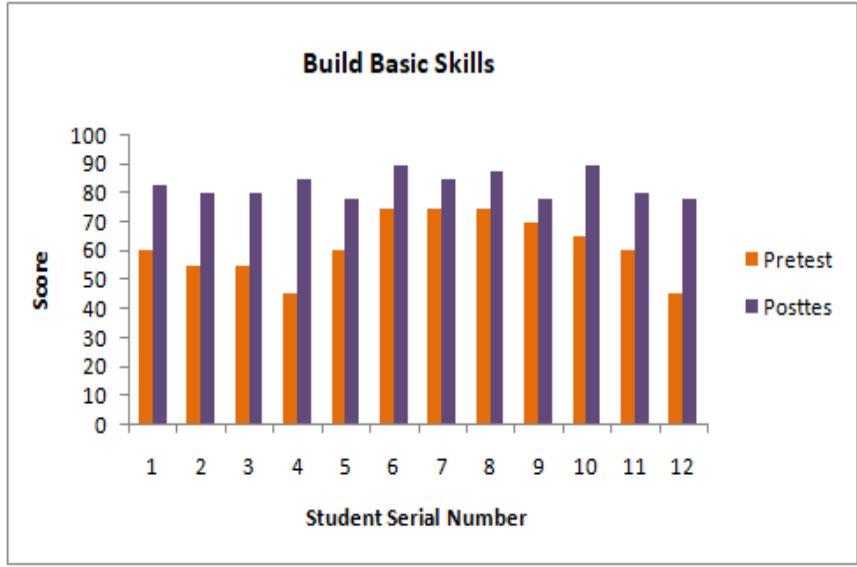

Figure 5. The result of Increasing Critical Thinking with Indicators building basic skills

Figure 5 showed that the lowest pretest score was 45 and the highest score was90. While the lowest posttest score was 78 and the highest score was 90 . There were 3 students who got 75 and increased about $10-15$ point after using the media. The students who got below 75 in pre-test increased in the posttest because they were diligent and persistent in learning where the $\mathrm{N}$-Gain score was categorized as high. The ability of students to analyze the results of observations is better by conveying simple explanations,. The students were not brave to express their opinions in front of friends. In the basic skills, it is easier to understand the material if the objects are real or concrete so that researchers bring form and function into the Encyclopedia book as a learning medium and use student worksheet as an evaluation worksheet in many activities related to plants around linked to Piaget's theory of cognitive development (Santrock, 2009) at the concrete operational stage at the age of 7-11 years children think by seeing real objects more easily understand it.

The results of critical thinking skills on making conclusions at the end of learning are presented in Figure 6.

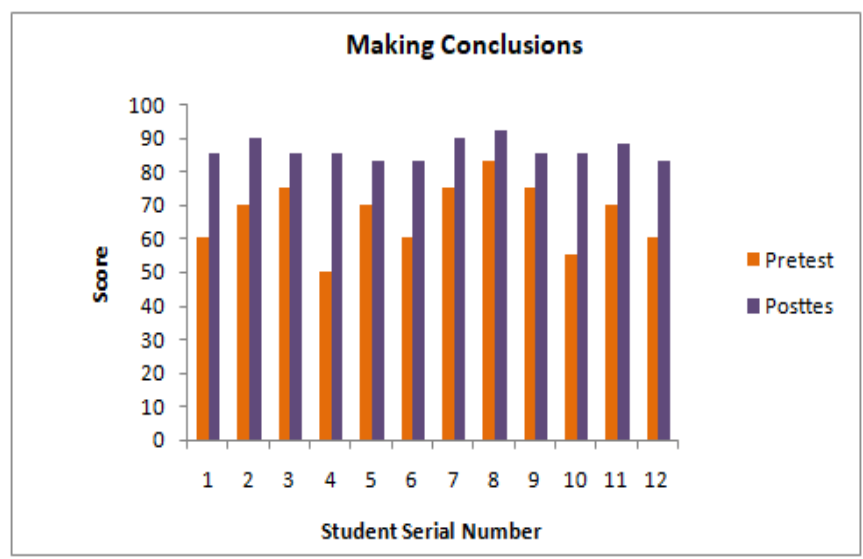

Figure 6. Results of Critical Thinking with Indicators Making Conclusions
Figure 6 showed that the lowest score was 50 and the highest score was 80 in pretest, while the lowest posttest score was 83 and the highest one was 92. In making conclusion indicator, the posttest score was between 80-92. Of the three indicators of critical thinking in $\mathrm{N}$-Gain, students with serial numbers 3, 5 and 9 obtained 0.15 , categorized as moderate criteria. While the N-Gain scores of other students got high criteria.

Student responses are the opinions of students about the Encyclopedia media on Form and Function of Plant which are used as a medium to improve students' critical thinking skills. Questionnaire were given to 12 students on a limited scale trial after learning. The results of the questionnaire analysis of students' responses to media Encyclopedia on Forms and Functions of Plant and critical thinking test questions were $97 \%$ who answered "yes" with very strong criteria and those who answered "no" between $3 \%$. Students on limited trials gave positive responses to the media. The analyzed data became the supporting data of the Encyclopedia on Form and Function of plant can be used as a medium in learning science about Plant material.

\section{CONCLUSION}

Referring to the results of the analysis and discussion, it can be concluded that (1) The validation of developed Encyclopedia media and learning tools have met the validity criteria based on the results of the validator's report so that the developed media is feasible to be used in the learning activities. (2) Practical development of Encyclopedia media with Discovery Learning learning models seen from the implementation in the classroom is categorized as very good in meeting one, two and three. (3) The effectiveness of the developed Encyclopedia media is seen from the results of critical thinking learning that increases and there is a very good response so it is feasible to be used in the learning activities.

\section{REFERENCES}

Ahmatika, Deti. (2018). Peningkatan Kemampuan Berpikir Kritis siswa dengan Pendekatan Inquiry/Discovery. Bandung: Jurnal Euclid, ISSN 2355-1712, Vol 3 No. 1 p. 394

Arikunto, S. (2010). Prosedur Penelitian Suatu Pendekatan Praktik. Jakarta: Rineka Cipta.

Borich. (1994). Observation Skills for EffectiveTeaching. New York: Merril Publishing Company.

Deti, A. (2019). Peningkatan Kemampuan Berpikir Kritis Siswa dengan Pendekatan Inquiry/Discovery. Bandung: Jurnal Euclid, Vol 3, No. 1, p.394.

Firdha Bella, d. (2019). The Development of Plant Encyclopedia Based on Database in Adiwiyata Senior High School. Semarang: Jurnal of Biology Eucation 8(1) (2009): 1-7. 
Hake, R. (1999). Analyzing Change/Gain Score. AREA-D America Education Research Association's Devision. D, Measurement and Reasearch Methodology. AMERICAN.

Hafrah, M. \&. (2015). Pengaruh model Pembelajaran Discovery Learning terhadap Kemampuan Berpikir Kritis Ditinjau dari Gaya Belajar Peserta Didik Kelas XI IPA SMAN 4 Bantaeng. Makasar.

Huda, C., Damayanti, F., \& Nuvitalia, D. (2019). Analisis Validasi dan Reliabilitas Alat Peraga Tabung Resonansi Horizontal beserta Instrumennya untuk Menunjang Keterampilan Generik Sains Siswa. Physics Education Research Journal Vol. 1 No. 1 (2019), 1-10. P-ISSN: 2685-6190.

Hidayati, R. (2016). Layanan penguasaan Konten dengan Media Ular Tangga untuk Meningkatkan Keterampilan Berpikir Kritis Siswa Sekolah Dasar. Kudus: Jurnal Konseling GUSJIGANG Vol. 2 No. 1 Print ISSN 2460-1187.

Ibrahim, M. (2005). ASESMEN BERKELANJUTAN" Konsep dasar, tahapan pengembangan dan contoh". Surabaya: Unesa University Press.

Iskandar, Budijanto \& Amirudin. 2016. Pengembangan Buku Teks Geografi dengan Struktur Penulisan Ensiklopedia. Malang: Jurnal Pendidikan Teori, Penelitian dan Pengembangan Vol 1 No. 2 hal 137-143

Jodian, d. (2019). The Correlation Between Critical and Creative Thinking Skills on Cognitive Learning Results. Jambi: Eurasian Journal of Educational Research 81 (2019) 99-114.

Munadi, Y. (2013). Media Pembelajaran . Jakarta: Referensi (GP Press Group).

Mustaji. (2013). Media Pembelajaran . Surabaya: Unesa University Press.

Pebriana, R. (2017). Effeect of Problem Based Learning to Critical Thinking Skills Elementary School Students in Sosial Studies. Bandung: Journal of Elementary Education Vol. 1, No 1. p. 109-118.

Prihartanta, W. (2015). Ensiklopedia Umum. Banda Aceh: Jurnal Adabiya, Vol 5 No.85.

Riduwan. (2010). Konversi Dasar-Dasar Statistik. Bandung: Alfabeta.

Setyosari, P. (2010). Metode Penelitian Pendidikan dan Pengembangan. Jakarta: Kencana Prenada Media Group.

Shahzada, S. a. (2017). Role Play: A Productive Teaching Strategy to Promote Critical Thinking. Township Lahore: Bulletin of Education and Research.

Siti Imma, Y. (2019). Pengembangan Modul Tematik Integratif Berbasis Character Building. Malang: Jurnal Bidang Pendidikan Dasar (JBPD), 3 (1).

Sugiyono. (2013). Metode Penelitian Kuantitatif, Kualitatif dan R\&D. Bandung: ALFABETA.

Supriatin, D. (2018). Use Of Digital Encyclopedia Media
To Develop Cognitive Aspects Of. Cimahi: Jurnal Emprowerment, 7(2), 81-87.

Trisnawati, R. N. (2018). Pengaruh Pembelajaran IPA Berbasis Empat Pilar Pendidikan terhadap Kemampuan Berpikir Kritis. Indonesia: JIPVA (Jurnal Pendidikan IPA Veteran) Vol.2 nomer 2, P. 162-173.

Zubaidah, S. (2010). Berpikir Kritis: Kemampuan Berpikir Tingkat Tinggi yang dapat Dikembangkan melalui Pembelajaran Sains. Malang:

https://www.researchgate.net/publication/318040409 